\title{
Copper Adsorption from Wasterwater Using Bone Charcoal
}

\author{
Sana Ghrab1, Mourad Benzina ${ }^{1}$, Stéphanie D. Lambert ${ }^{2}$ \\ ${ }^{1}$ Laboratoire Eau Environnement Energie, Ecole National d'Ingénieur, Sfax, Tunisie \\ ${ }^{2}$ Department of Chemical Engineering, University of Liège, Liège, Belgium \\ Email: stephanie.lambert@ulg.ac.be
}

How to cite this paper: Ghrab, S., Benzina, M. and Lambert, S.D. (2017) Copper Adsorption from Wasterwater Using Bone Charcoal. Advances in Materials Physics and Chemistry, 7, 139-147.

https://doi.org/10.4236/ampc.2017.75012

Received: March 8, 2017

Accepted: May 6, 2017

Published: May 9, 2017

Copyright $\odot 2017$ by authors and Scientific Research Publishing Inc. This work is licensed under the Creative Commons Attribution International License (CC BY 4.0).

http://creativecommons.org/licenses/by/4.0/

\begin{abstract}
Bone charcoal (BC) is being developed as a treatment for decontamination of polluted water. In this study, bone charcoal was obtained by pyrolysis of cow bones and tested for the elimination of copper from aqueous solutions. The minimum time to reach the removal equilibrium by adsorption was $10 \mathrm{~min}$ with a maximum of copper removal equal to $9615 \mathrm{mg} / \mathrm{g}$. Different kinetics models were applied to fit the experimental data: the pseudo second-order model correlated the results with a linear correlation coefficient equal to 1 .
\end{abstract}

\section{Keywords}

Adsorption, Copper, Bone Charcoal, Wastewater

\section{Introduction}

Heavy metals are inorganic pollutants frequently found in the wastewaters of several industries such as electroplating, mining, metal processing, petroleum refining, textile, tanneries, paint manufacture, pesticides, battery manufacturing, pigment manufacture, photographic industries and printing [1] [2] [3]. These inorganic pollutants have a negative impact on the environment and modify the physical and chemical characteristics of water and soil [4] [5], and the properties of aquatic fauna and flora [6]. Furthermore, the presence of heavy metal ions in industrial wastewater, irrigation and drinking water resources has also high negative impacts on human health due to their toxicity [7]. So the elimination of these heavy metals from wastewaters is one of the most important environmental problems for research, engineering and technology development on water management in environment [8] [9].

The purification of heavy metals contaminated wastewaters can be realized by chemical precipitation [8], ions exchanges membranes [10], electrochemical 
systems [11] [12], electrodialysis [13], coagulation-flocculation [14] [15] and removal by materials adsorption [16] [17]. This last method is very economic and efficient to improve the water quality. In this aim, different materials have been used to adsorb heavy metals, such as activated sludge [18], synthetic adsorbents [19] [20], biosorbents [21] and clays [22] [23]. The adsorbent materials must be cheap, easy to operate and simple for design.

The objective of this study is to develop cheap and effective adsorbents from the biological wastes, such as cow bone, to replace the classical commercial adsorbents. So cow bone from which the bone charcoal was derived, is used as an adsorbent and investigated for its adsorption properties towards copper ions. The influences of different experimental parameters, such as the amount of BC and the contact time, have been investigated. Different kinetics models were also applied to fit the experimental data.

\section{Materials}

\subsection{Adsorbate}

A stock of copper solution ( $888.7 \mathrm{ppm}$ ) was prepared by dissolving $\mathrm{CuSO}_{4} \cdot 5 \mathrm{H}_{2} \mathrm{O}$ in distilled water.

\subsection{Sample Preparation}

Cortical bovines have been collected from the local slaughter houses in Sfax, Tunisia. The bone samples have been washed and cleaned using boiling method to eliminate organic substances and collagen, to avoid soot developing in the material during the pyrolysis process. Cow bones were boiled in water for $3 \mathrm{~h}$ at $99.5^{\circ} \mathrm{C}$. Then the water was eliminated and the bones were washed using fresh water [24]. At this moment, the bones were dried in an oven at $80^{\circ} \mathrm{C}$. The dried bones were crushed and milled into different particle sizes and after calcined for $2 \mathrm{~h}$ at $800^{\circ} \mathrm{C}$ with a mixture of oxygen/nitrogen (25/75 vol\%) [25]. The resulting material was denominated as Bone Charcoal (BC). The resulted BC was crushed again and refined to obtain a powder with particles sizes $<50 \mu \mathrm{m}$ and finally stored in hermetic bottles for subsequent uses.

\subsection{Instrumental}

Carbonization was carried out in a vertical stainless-steel reactor (length $=170$ $\mathrm{mm}$, internal diameter $=22 \mathrm{~mm}$ ), which was placed into a cylindrical electric furnace Nabertherm. Mineralogical analysis of the $\mathrm{BC}$ sample was realized by $\mathrm{X}$-ray diffraction (Bruker D8) and showed the characteristic peaks of amorphous carbon [26]. An IR transmittance spectrum of the BC sample was carried out in the $500-2000 \mathrm{~cm}^{-1}$ range using a SHIMATZU IR 470 spectrometer. The specific surface area $\left(\mathrm{m}^{2} / \mathrm{g}\right)$ of $\mathrm{BC}$ was determined from nitrogen adsorption-de- sorption isotherm with the Brunauer-Emmett-Teller (BET) method. The macroporous volume of $\mathrm{BC}$ was measured by mercury intrusion porosimetry (Joschek et al., 2000). The concentration of copper was carried out by atomic absorption spectrometry (HITACHI Z-6100). 


\section{Methods}

\subsection{Adsorption Experiments}

The adsorption experiments were determined according to the batch experiments at room temperature $\left(25^{\circ} \mathrm{C}\right) .0 .1 \mathrm{~g}$ of $\mathrm{BC}$ was mixed with a $50 \mathrm{~mL}$ of copper solution at different concentrations $(0-500 \mathrm{mg} / \mathrm{L})$. The deviation of the $p H$ of the contaminated heavy metal solution during copper adsorption was measured for all experiments, with an experimental deviation $= \pm 1$. The initial $p H$ was fixed $<5.5$ to avoid precipitation of $\mathrm{Cu}(\mathrm{OH})_{2}$.

The quantity of adsorbed copper, $q_{p}$ on BC is calculated according to Equation (1):

$$
q_{t}=\frac{\left(C_{0}-C_{e}\right)}{m} V
$$

where $C_{o}$ is the initial concentration of copper $(\mathrm{mg} / \mathrm{L}), C_{e}$ is the residual concentration of copper $(\mathrm{mg} / \mathrm{L}), m$ is the mass of $\mathrm{BC}(\mathrm{g})$ and $V$ is the volume of the copper solution (L).

\subsection{Adsorption Kinetics Modeling}

In order to examine the mechanism of adsorption processes, the pseudo firstorder adsorption, the pseudo second-order adsorption and the intraparticle diffusion models were used to adjust kinetic experimental data. The amount of BC sample $(0.25 \mathrm{~g})$ is mixed with a $50 \mathrm{~mL}$ of copper solution $(10 \mathrm{mg} / \mathrm{L})$ to carry out adsorption experiments in bath mode.

\subsubsection{Pseudo First-Order Model}

The pseudo first-order rate expression of Lagergren is usually described by the following Equations (2) and (3) [27]:

$$
\frac{\mathrm{d} q_{t}}{\mathrm{~d} t}=K_{1}\left(q_{e}-q_{t}\right)
$$

where $q_{e}$ is the amount of copper adsorbed on $\mathrm{BC}$ at the equilibrium time $(\mathrm{mg} / \mathrm{g}), q_{t}$ is the amount of copper adsorbed on BC at time $t(\mathrm{mg} / \mathrm{g})$ and $K_{1}$ is the rate constant of pseudo first-order adsorption ( $1 / \mathrm{min})$. Integrating and applying the boundary condition, for $t=0, q_{t}=0$ and for $t=t, q_{e}=q_{t}$ Equation (2) takes the following form:

$$
\frac{1}{q_{t}}=\frac{K_{1}}{q_{e} t}+\frac{1}{q_{e}}
$$

where $K_{1}$ was determined from the slope of linear plot of $1 / q_{t}$ against $1 / t$.

\subsubsection{Pseudo Second-Order Model}

The pseudo second-order mechanism for adsorption is shown in Equation (4) [28] [29]:

$$
\frac{\mathrm{d} q_{t}}{\mathrm{~d} t}=K_{2}\left(q_{e}-q_{t}\right)^{2}
$$

where $q_{t}$ is the adsorption capacity at time $t(\mathrm{mg} / \mathrm{g}), K_{2}$ is the rate constant of 
pseudo second-order adsorption ( $1 / \mathrm{min})$. Integration and applying the boundary conditions, for $t=0, q_{t}=0$ and for $t=t, q_{e}=q_{t}$ Equation (4) takes the following form:

$$
\frac{t}{q_{t}}=\frac{1}{K_{2} q_{e}^{2}}+\frac{1}{q_{e}} t
$$

If the second order kinetic model is applicable, the plot of $t / q_{t}$ against $t$ of Equation (5) should give a linear relationship from which $q_{e}$ and $K_{2}$ can be established.

\subsubsection{Intraparticle Diffusion Model}

The intraparticle diffusion model presented by Allen et al. [30] could be a ratelimiting step and is shown in Equation (6):

$$
q_{t}=K_{3} t^{1 / 2}+C
$$

where $q_{t}$ is the adsorption capacity at time $t(\mathrm{mg} / \mathrm{g}), K_{3}$ is the intraparticle diffusion rate constant $\left(\mathrm{mg} /\left(\mathrm{g} \cdot \mathrm{min}^{1 / 2}\right)\right)$ and $C$ is the intercept.

\subsection{Copper Desorption}

Desorption studies were performed in two phases [31]:

Phase 1: Adsorption. $0.25 \mathrm{~g}$ of $\mathrm{BC}$ was placed in contact with $50 \mathrm{~mL}$ of a 50 $\mathrm{mg} / \mathrm{L}$ of copper solution. BC was then collected by filtration, washed with distilled water and placed in an oven for $12 \mathrm{~h}$ at $60^{\circ} \mathrm{C}$. The liquid phase was analyzed by AAS (HITACHI).

Phase 2: Desorption. The dry and saturated BC was placed in contact with 50 $\mathrm{mL}$ of $0.1 \mathrm{M} \mathrm{HCl}, \mathrm{NaOH}, \mathrm{NaCl}$ and distilled water for $2 \mathrm{~h}$. The liquid phase was filtered and analyzed by AAS (HITACHI). The desorbed copper percentage was determined according to Equation (7):

$$
\% \text { desorption }=\frac{Q_{d e s}}{Q_{a d s}} \times 100
$$

where $Q_{d e s}$ is the amount of desorbed copper from BC $(\mathrm{mg} / \mathrm{g})$ and $Q_{a d s}$ is the amount of copper adsorbed onto BC (mg/g).

\section{Results and Discussion}

\subsection{Characterization of Bone Charcoal (BC)}

The bones are composed of inorganic (65 wt\%) and organic (35 wt\%) components. The principal inorganic component of bone is hydroxyapatite, $\mathrm{Ca}_{10}\left(\mathrm{PO}_{4}\right)_{6}(\mathrm{OH})_{2}(\mathrm{HA})$. Figure 1 shows the FTIR spectrum in the $500-2000 \mathrm{~cm}^{-1}$ range of BC. Only the bands characteristic of HA $\left(554-960 \mathrm{~cm}^{-1}\right)$ are presented [32]. The diffractogram of $\mathrm{BC}$ (not shown here) shows only the characteristic pattern of HA. These results confirm that the organic components are eliminated from the bone samples after calcination at $800^{\circ} \mathrm{C}$ for $2 \mathrm{~h} \mathrm{[32]} \mathrm{[33].}$

The specific surface area of $\mathrm{BC}, S_{\mathrm{BET}}$, is equal to $75 \mathrm{~m}^{2} / \mathrm{g}$ and the macroporous (pore size $>50 \mathrm{~nm}$ ) volume of $\mathrm{BC}$, determined by mercury porosimetry, is equal to $0.9 \mathrm{~cm}^{3} / \mathrm{g}$. 


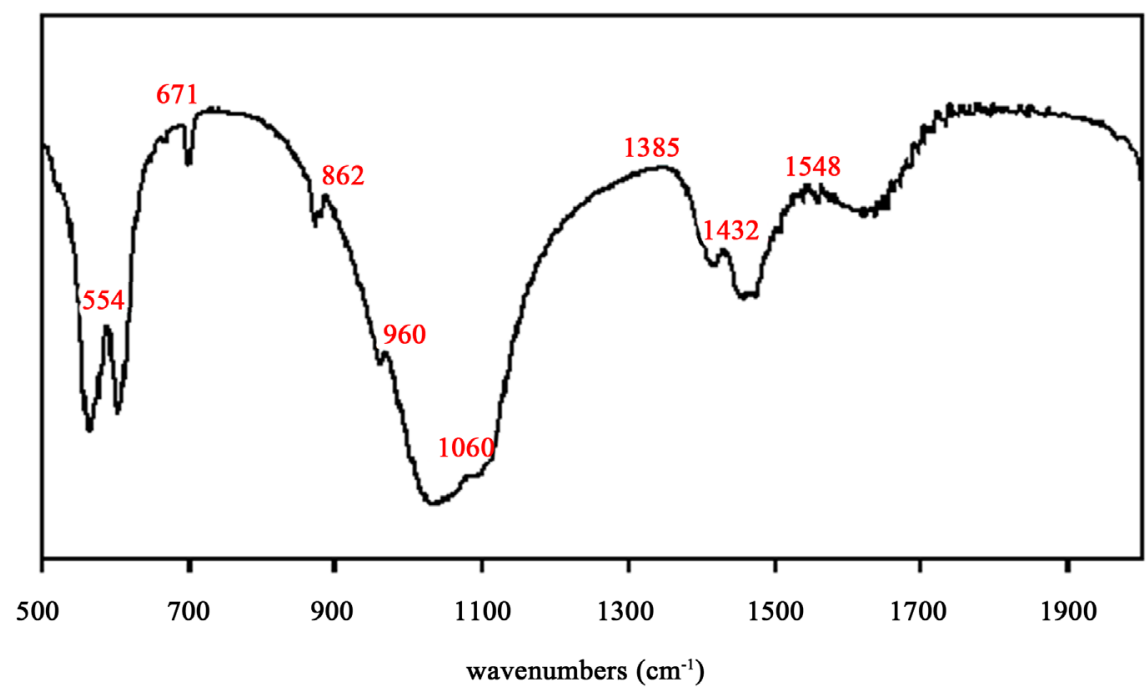

Figure 1. FTIR spectrum of bone charcoal.

\subsection{Kinetic Studies}

Figure 2 shows the effect of contact time, $t$, on the removal of $50 \mathrm{mg} / \mathrm{L}$ of $\mathrm{Cu}$ by BC. The adsorption of $\mathrm{Cu}$ increases with time to reach an equilibrium after 10 min of mixing and agitation (red points in Figure 2).

The three kinetic models explained in paragraph 3.2 are used in this study and the results are shown in Figures 3-5. The values of coefficients for the three models are calculated. The correlation coefficient for the pseudo second-order kinetic model is higher $\left(R^{2}=1\right.$, Figure 4$)$ than both other models. This result indicates that the copper adsorption is controlled by a chemisorption process at the surface of BC [34]. The rate constant of pseudo second-order adsorption, $K_{2}$, represents the number of exchanges between $\mathrm{Ca}$ ions in $\mathrm{BC}$ and $\mathrm{Cu}$ ions present in aqueous solution [35]. Furthermore, the theoretical $q_{e}$ values acquired from the pseudo second-order kinetic model are in accordance with the experimental $q_{e}$ values.

\subsection{Copper Desorption}

Figure 6 shows the percentage of desorbed copper for the four different chemical agents used in this study. $\mathrm{HCl}$ shows the highest efficiency with approximately $2.521 \%$ of desorbed copper in $2 \mathrm{~h}$. None of the used solutions provoke any apparent physical damages to the adsorbent. Nevertheless, the desorption level of copper with 3 types of aqueous solution (alkaline, neutral and acidic) remains very low. This confirms the strong covalent bonds established between $\mathrm{BC}$ and copper ions. So, to regenerate $\mathrm{BC}$, treatments at high temperatures are necessary to break the bonds between $\mathrm{BC}$ and copper ions.

\section{Conclusions}

This study investigates heavy metal ions adsorption onto economical Bone Charcoal (BC) adsorbent originating from cow bones. This adsorbent seems to 


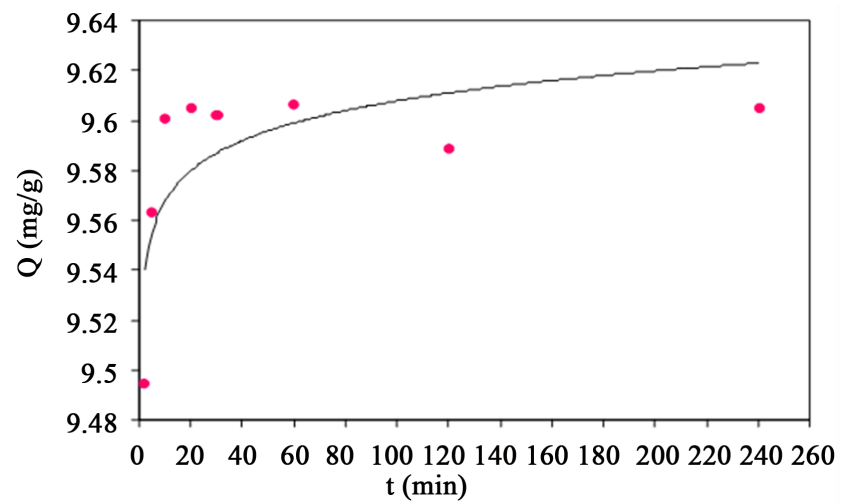

Figure 2. Effect of contact time on copper adsorption onto BC.

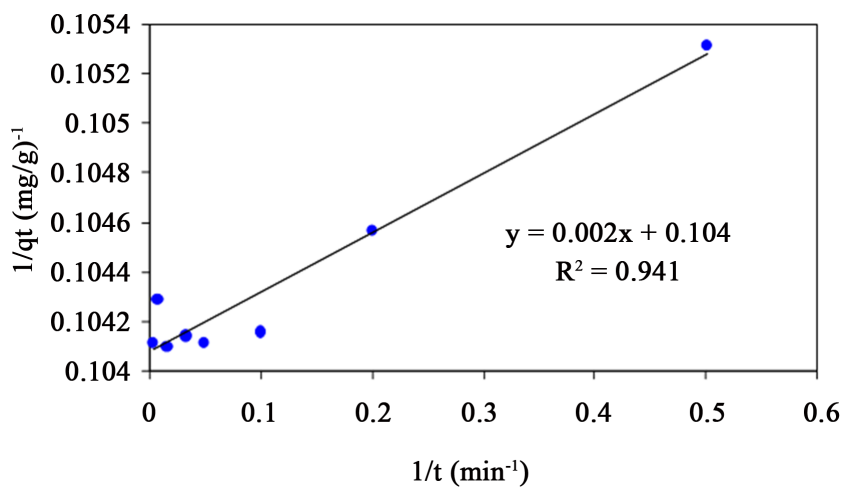

Figure 3. Pseudo first-order kinetic model of copper adsorption onto BC.

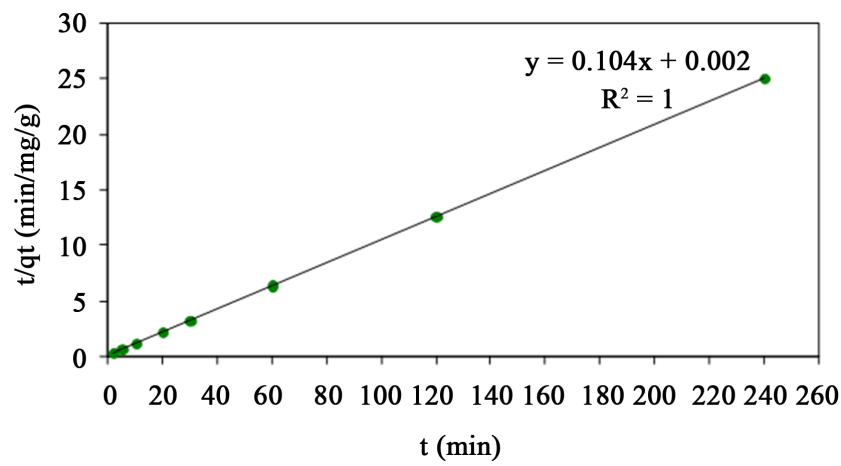

Figure 4. Pseudo second-order kinetic model of copper adsorption onto BC.

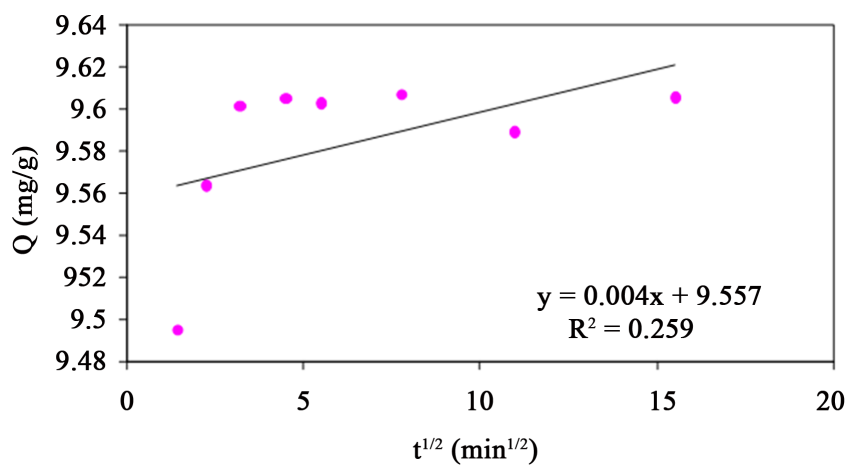

Figure 5. Intraparticle diffusion kinetic model of copper adsorption onto BC. 


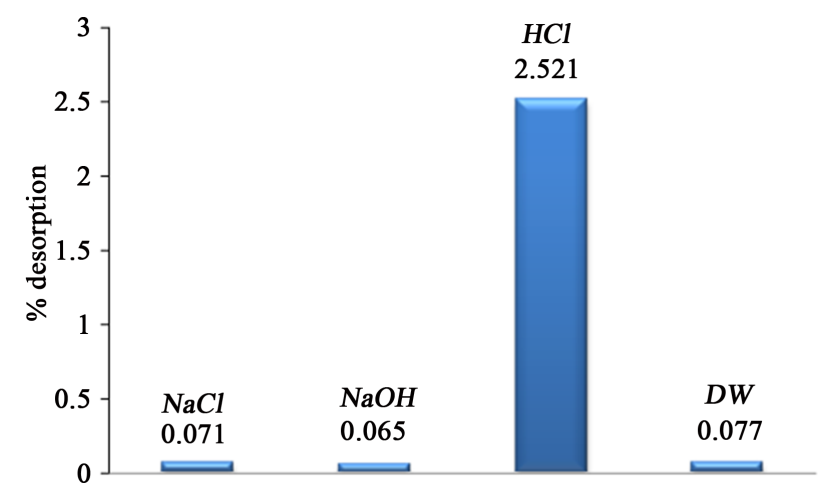

Figure 6. Copper desorption from $\mathrm{BC}$ using different chemical desorption reagents.

be efficient to remove the maximum of copper pollution from water, with $0.1 \mathrm{~g}$ of BC amount after $10 \mathrm{~min}$. The kinetic studies of copper adsorption on BC indicate that the pseudo second-order model is the most adequate. This result indicates that the copper adsorption is controlled by a chemisorption process at the surface of BC. Although it is potentially a new alternative for the elimination of heavy metals from polluted water, the desorption of copper ions is difficult by the existence of strong covalent bonds between BC and copper ions.

\section{Acknowledgements}

One of us (S. D. L) thanks to the Belgian "Fonds National de Recherche Scientifique” (FRS-FNRS) for her Associate Research position. Furthermore, one other of us (S. G.) thanks to the Laboratory of Water, Environment and Energy, Sfax, Tunisia for the financial funds.

\section{References}

[1] Fuge, R. (2013) Anthropogenic Sources. In: Selinus, O., Ed., Essentials of Medical Geology: Revised Edition, Springer Science and Business Media, Dordrecht, 59-74. https://doi.org/10.1007/978-94-007-4375-5_4

[2] Ahmaruzzaman, M. (2011) Industrial Wastes as Low-Cost Potential Adsorbents for the Treatment of Wastewater Laden with Heavy Metals. Advances in Colloid and Interface Science, 166, 36-59.

[3] Kadirvelu, K., Thamaraiselvi, K. and Namasivayam, C. (2001) Removal of Heavy Metals from Industrial Wastewaters by Adsorption onto Activated Carbon Prepared from an Agricultural Solid Waste. Bioresource Technology, 76, 63-65.

[4] Houda, B., Dorra, G., Chafai, A., Emna, A. and Khaled, M. (2011) Impact of a Mixed "Industrial and Domestic" Wastewater Effluent on the Southern Coastal Sediments of Sfax (Tunisia) in the Mediterranean Sea. International Journal of Environmental Research, 5, 691-704.

[5] Guptaa, S., Nayeka, S. and Sahab, R.N. (2010) Temporal Changes and Depth Wise Variations in Pit Pond Hydrochemistry Contaminated with Industrial Effluents with Special Emphasis on Metal Distribution in Water-Sediment System. Journal of Hazardous Materials, 183, 125-131.

[6] Das, D., Charumathi, D. and Das, N. (2011) Bioaccumulation of the Synthetic Dye Basic Violet 3 and Heavy Metals in Single and Binary Systems by Candida tropicalis Grown in a Sugarcane Bagasse Extract Medium: Modelling Optimal Conditions 
Using Response Surface Methodology (RSM) and Inhibition Kinetics. Journal of Hazardous Materials, 186, 1541-1552.

[7] Amin, N., Hussain, A., Alamzeb, S. and Begum, S. (2013) Accumulation of Heavy Metals in Edible Parts of Vegetables Irrigated with Waste Water and Their Daily Intake to Adults and Children, District Mardan, Pakistan. Food Chemistry, 136, $1515-1523$.

[8] Kurniawan, T.A., Chan, G.Y.S., Lo, W.H. and Babel, S. (2006) Physico-Chemical Treatment Techniques for Wastewater Laden with Heavy Metals. Chemical Engineering Journal, 118, 83-98.

[9] Fu, F. and Wang, Q. (2011) Removal of Heavy Metal Ions from Wastewaters: A Review. Journal ofEnvironment Management, 92, 407-418.

[10] Kolodynska, D., Geca, M., Siek, M. and Hubicki, Z. (2013) Nitrilotris(Methylenephosphonic) Acid as a Complexing Agent in Sorption of Heavy Metal Ions on Ions Exchangers. Chemical Engineering Journal, 215-216, 948-958.

[11] Kim, G., Ebenezer, T., George, Z. and Chen, A. (2014) A Sunlight Assisted Dual Purpose Photoelectrochemical Cell for Low Voltage Removal of Heavy Metals and Organic Pollutants in Wastewater. Chemical Engineering Journal, 244, 411-421.

[12] Tao, H.C., Lei, T., Shi, G., Sun, X.-N., Wei, X.-Y., Zhang, L.-J. and Wu, W.-N. (2014) Removal of Heavy Metals from Fly Ash Leachate Using Combined Bioelectrochemical Systems and Electrolysis. Journal of Hazardous Materials, 264, 1-7.

[13] Mohammadi, T., Moheb, A., Sadrzadeh, M. and Razmi, A. (2005) Modeling of Metal Ion Removal from Wastewater by Electrodialysis. Separation and Purification Technology, 41, 73-82.

[14] Bratskaya, S.Y., Pestov, A.V., Yatluk, Y.G. and Avramenko, V.A. (2009) Heavy Metals Removal by Flocculation/Precipitation Using $N$-(2-Carboxyethyl)Chitosans. Colloids and Surfaces $A, 339,140-144$.

[15] Pang, F.M, Kumar, P., Teng, T.T., Mohd Omar, A.K. and Wasewar, K.L. (2011) Removal of Lead, Zinc and Iron by Coagulation-Flocculation. Journal of the Taiwan Institute of Chemical Engineers, 42, 809-815.

[16] Chaari, I., Fakhfakh, E., Chakroun, S., Bouzid, J. and Boujelben, N. (2008) Lead Removal from Aqueous Solutions by a Tunisian Smectitic Clay. Journal of Hazardous Materials, 156, 545-551.

[17] Boujelben, N., Bouzid, J. and Elouear, Z. (2009) Adsorption of Nickel and Copper onto Natural Iron Oxide-Coated Sand from Aqueous Solutions: Study in Single and Binary Systems. Journal of Hazardous Materials, 163, 376-382.

[18] Moisés, T.P., Patricia, B.H., Barrera-Díaz, B.E., Gabriela, R.M. and Natividad-Rangel, R. (2010) Treatment of Industrial Effluents by a Continuous System: Electrocoagulation-Activated Sludge. Bioresource Technology, 101, 7761-7766.

[19] Naiya, T.K., Bhattacharya, A.K. and Das, S.K. (2009) Adsorption of Cd(II) and $\mathrm{Pb}$ (II) from Aqueous Solutions on Activated Alumina. Journal of Colloid and Interface Science, 333, 14-26.

[20] Ji, F., Li, C., Tang, B., Xu, J. and Lu, G. (2012) Preparation of Cellulose Acetate/ Zeolite Composite Fiber and Its Adsorption Behavior for Heavy Metal Ions in Aqueous Solution. Chemical Engineering Journal, 209, 325-333.

[21] Zafar, M.N., Nadeemb, R. and Hanif, M.A. (2007) Biosorption of Nickel from Protonated Rice Bran. Journal of Hazardous Materials, 143, 478-485.

[22] Yavuz, O.M., Altunkaynak, Y. and Fuat, G. (2003) Removal of Copper, Nickel, Cobalt and Manganese from Aqueous Solution by Kaolinite. Water Research, 37, 948952. 
[23] Ghrab, S., Boujelben, N., Medhioub, M. and Jamoussi, F. (2014) Chromium and Nickel Removal from Industrial Wastewater Using Tunisian Clay. Desalination and Water Treatment, 52, 2253-2260. https://doi.org/10.1080/19443994.2013.805165

[24] Toque, J.A., Herliansyah, M.K., Hamdi, M., Ide-Ektessabi, A. and Wildan, A.M. (2007) The Effect of Sample Preparation and Calcination Temperature on the Production of Hydroxyapatite from Bovine Bone Powders. Proceedings of the 3rd Kuala Lumpur International Conference on Biomedical Engineering, Kuala Lumpur, Malaysia,11-14 December 2007, 152-155.

[25] Moreno-Piraján, J.C. and Giraldo, L. (2010) Adsorption of Copper from Aqueous Solution by Activated Carbons Obtained by Pyrolysis of Cassava Peel. Journal of Analytical Applied Pyrolysis, 87, 188-193.

[26] Job, N., Heinrichs, B., Ferauche, F., Noville, F., Marien, J. and Pirard, J.P. (2005) Hydrodechlorination of 1,2-Dichloroethane on Pd-Ag Catalysts Supported on Tailored Texture Carbon Xerogels. Catalysis Today, 102-103, 234-241.

[27] Srihari, V. and Das, A. (2008) The Kinetic and Thermodynamic Studies of PhenolSorption onto Three Agro-Based Carbons. Desalination, 225, 220-234.

[28] Wu, F.C., Tseng, R.L. and Juang, R.S. (2001) Kinetic Modeling of Liquid-Phase Adsorption of Reactive Dyes and Metal Ions on Chitosan. Water Research, 35, 613618.

[29] Antonioa, P., Iha, K. and Suárez-Iha, M.E.V. (2007) Kinetic Modeling of Adsorption of Di-2-Pyridylketone Salicyloylhydrazone on Silica Gel. Journal of Colloid and Interface Science, 307, 24-28.

[30] Allen, S.J., Mckay, G. and Khader, K.Y.H. (1989) Intraparticle Diffusion of a Basic Dye During Adsorption onto Sphagnum Peat. Environmental Pollutions, 56, 39-50.

[31] Cechinel, M.A.P., Ulson de Souza, S.M.A.G. and Ulson de Souza, A.A. (2014) Study of Lead (II) Adsorption onto Activated Carbon Originating from Cow Bone. Journal of Cleaner Products, 65, 342-349.

[32] Figueiredo, M., Fernando, A., Martins, G., Freitas, J. and Judas, F. (2010) Effect of the Calcination Temperature on the Composition and Microstructure of Hydroxyapatite Derived from Human and Animal Bone. Ceramics International, 36, 23832393.

[33] Barakat, N.A.M., Khalil, K.A., Faheem, A., Sheikh, A.M. and Omran, M. (2008) Physiochemical Characterizations of Hydroxyapatite Extracted from Bovine Bones by Three Different Methods: Extraction of Biologically Desirable. Materials Science and Engineering $C, 28,1381-1387$.

[34] Pérez, J.T., Solache-Rıos, M. and Colın-Cruz, A. (2008) Sorption and Desorption of Dye Remazol Yellow onto a Mexican Surfactant-Modified Clinoptilolite-Rich Tuff and a Carbonaceous Material from Pyrolysis of Sewage Sludge. Water, Air, and Soil Pollution, 187, 303-313. https://doi.org/10.1007/s11270-007-9518-6

[35] Hassan, S.S.N., Awwad, S.N. and Aboterika, A.H.A. (2008) Removal of Mercury(II) from Wastewater Using Camel Bone Charcoal. Journal of Hazardous Materials, 154, 992-997. 
Submit or recommend next manuscript to SCIRP and we will provide best service for you:

Accepting pre-submission inquiries through Email, Facebook, LinkedIn, Twitter, etc. A wide selection of journals (inclusive of 9 subjects, more than 200 journals)

Providing 24-hour high-quality service

User-friendly online submission system

Fair and swift peer-review system

Efficient typesetting and proofreading procedure

Display of the result of downloads and visits, as well as the number of cited articles Maximum dissemination of your research work

Submit your manuscript at: http://papersubmission.scirp.org/

Or contact ampc@scirp.org 